\title{
An Afro-Existential Approach to the Development of the Nigerian Society
}

\author{
Oliver Ozoemena Onah ${ }^{1}$, Dr. Hyginus Chibuike Ezebuilo², Dr. Chinyere \\ Theodora Ojiakor ${ }^{3}$
}

\author{
${ }^{1}$ Post graduate student, University of Nigeria, Nsukka. \\ Email:ozemoson@yahoo.com \\ ${ }^{2}$ Nnamdi Azikiwe University, Awka \\ Email: frezebuilo@gmail.com \\ ${ }^{3}$ Department of English, Madonna University-Nigeria. \\ Email: tcorjiakor@gmail.com
}

\begin{abstract}
The role of philosophy in nation building is hardly given the recognition it deserves in the African society. In this regard, philosophers are often seen as those who see problems where none exist, rather than people who inspire critical thinking. Yet, the role of philosophy in nation building cannot be dismissed with a wave of hand. The focus of this paper is basically to establish the relevance of existentialist philosophy to national development. To this end, we situate our discourse within a particular African context. The African world view would be discussed mainly from the context of the Igbo world view. This is the crux of the whole work. To this effect, the full implication of the Afro-existential approach will unfold as the work unfolds. One branch of philosophy that has made waves in various disciplines is existentialism. This paper is therefore an attempt to establish the relevance of existentialist philosophy to national development, with a particularfocus on Nigeria. It understands existentialismas a trend in philosophy that lays emphasis on man's existence with regard to such themes as
\end{abstract} individual freedom and choice, and the individual creating meaning in a meaningless universe. In this connection, it examines the role of the Afro-existential discourse as a new approach in African philosophy. It addresses such questions as, why is Nigeria underdeveloped. Do we have to continue looking for historical forces or factors to blame? What can the philosopher and the existential discourse contribute to the development of Nigeria? It concludes that, confronted with the underdeveloped state of Nigeria, the existentialists do not overly ignore history. However, they are more concerned with the present situation and the choices that confront us as individuals. Making the right choices and taking the right steps today is therefore the way philosophers would establish their relevance through the existential discourse.

www.ijels.com
Keywords-Afro-existential, Approach, development, Nigerian society.

\section{INTRODUCTION}

The term development, in a layman's understanding, is improvement. The Cambridge Dictionary defines development as "the process in which someone or something grows or changes and becomes more advanced." More technically, it refers to improvement in a country's economic and social conditions, or improvements in the way of managing an area's natural and human resources so as to create wealth and improve people's living standards (Shah, 2017, para. 1). Seers (1967) outline a number of conditions that should lead to the realization of the potentials of the human person. These, in a sense, would be indices of a developed society. They include (1) The capacity to obtain physical necessities, with particular reference to food (2) A job, which may or may not be a paid job (3) Equality (4) Participation in government (5) Belonging to a truly independent (economically and politically) nation (6) Adequate educational levels

The Nigerian society is a political contraption of Lord Frederick Lugard. Prior to the 1914 amalgamation and the coining of that appellation by Flora Shaw, what existed were various ethnic nationalities. Nigeria, as a nation, is located in West Africa, with a human population estimated at about $188,462,640$ in 2016. It is deemed the 7th most populous country in the world, occupying an area of 356,669 square miles as the 32nd largest country in the world (www.nationfacts.net/nigeria). Economically, Nigeria has relied almost solely on oil revenue which is largely controlled by a privileged few. In an oil rich country like Nigeria, the human development index is rated at 0.514 , at 152nd in the world as at 2015 (UNDP, 2015, p. 18). 


\section{THE PHILOSOPHY OF EXISTENCE}

Existentialism, as a branch of philosophy, defies any clearcut definition. Many attempts at the definition have come off as either too brief and one-sided or too lengthy. In this regard, we shall only attempt a description of the term. Existentialism then is a philosophy that focuses more and lays emphasis on man's existence. It beams its light on such themes as individual freedom and choice. One common view of the existentialists is that man is thrown into an irrational universe. Being so thrown into a meaningless or irrational universe the individual defines his or her own meaning in life. This is predominantly the view of the atheistic existentialist thinkers. There are also the theistic thinkers for whom belief in God bestows meaning upon the universe (Copleston, 1956, pp. 211-213).

For the atheistic existentialists the fact that there is no God or any other transcendent force creates a feeling of nothingness. The only way to counter this nothingness and subsequently create meaning in life is by embracing existence. Hence, existentialism focuses on living rather than making speculations about life. Existentialism has as its central thes is the notion that there is no ready-made, pre-existing human nature or essence. Each individual personality crystallizes through experience. Sartre, for instance, believes that since there is no fixed human nature, we are free to create ourselves, and subsequently we must take responsibility for what we make of ourselves (Simpson, 2016, para. 5). Sartre writes in this regard that "man first of all exists, encounters himself, surges up in the world - and defines himself afterwards. If man as the existentialist sees him is not definable, it is because to begin with he is nothing. He will not be anything until later, and then he will be what he makes of himself' (Sartre, 1973, p. 28). The logic is that the realization that we create ourselves and that everything about us could be different robs us of the tendency to pass the buck. We are unable to push responsibility onto something or someone else. Hence, in Sartrean terms, we are left alone without excuse (Sartre, 1973, p. 34).

Existentialism is of the view that individuals are free to make choices and decisions based on what appeals to them as meaningful rather than what is rational. For Kierkegaard, for instance, rationality is a mechanismhumans use to counter their existential anxiety; that is their fear of being in the world. Similarly, rationality is for Sartre a form of "bad faith," an attempt by the self to impose structure on a fundamentally irrational and random world of phenomena. This bad faith poses a hindrance to our discovery of meaning in freedom, and confines us within everyday experience.
Existentialism has often been studied by focusing on the themes commonly discussed by the existentialists. We shall highlight some of these themes to guide our study in this paper.

\section{a. Philos ophy as a way of life}

The existentialists do not conceive of philosophy as an effort geared towards investigating and understanding the self or the world, nor do they see it as a special occupation undertaken by a select few. It is rather an integral part of life. They do not object to there being professional philosophers who develop an elaborate set of methods and concepts. However, they believe that one who has not acquired a technical knowledge of philosophy can still live a life ruled by philosophy. Socrates, for instance, is today acclaimed a philosopher, but he never was a professional philosopher. He could be described as just trying to make sense out of nonsense. His intent was to instil a sense of the good life in people. In this sense he could pass for an existentialist. The professional philosophers would focus on propounding ideas and principles about life while the existentialists focus on engaging with life as it unfolds. In this regard, Kierkegaard, for example, believes that the fundamental truths of one's existence are not representations in terms of ideas, propositions or symbols the meaning of which can be separated from their origin. They are rather lived, felt and acted in the immediate (Burnham, 2018, para. 5). The philosopher is an insider to life, an actor.

\section{b. Anxiety and Authenticity}

Anxiety, angst or anguish is the recognition of the fact that man is a being on its own or abandoned in the universe, as the case may be. He is without a purpose or an essence. Other nuances may also apply (e.g. Kierkegaard irrelevance of rational thought, Heidegger - uniqueness of human existence).

Anxiety is closely related to authenticity. One who discovers one's thrownness either embraces the reality and lives it or engages in denial or false hope. An authentic being is the one who lives in accordance with his nature. For Kierkegaard, this is achieved through a leap of faith. For Heidegger, it is achieved through the existential choices of Dasein. For Buber, Marcel and Berdyaev, it is in communion and intersubjectivity. For Sartre, man is condemned to freedom and must choose resolutely even when there is no basis for the choices. Refusal to choose is bad faith (inauthenticity). The earlier Camus locates authenticity in the rejection of suicide, whether philosophical or physical, even amidst the absurdity of existence (Lescoe, 1974, p. 12).

\section{c. Freedom}


Freedom is also closely related to the concept of anguish. It is partially "defined by the isolation of my decisions from any determination by a deity, or by previously existent values or knowledge" (Burnham, 2018, para. 9). Freedom involves the liberty to choose one's actions and what to make of one's life and world as well as the responsibility for these choices and actions. For the existentialists, especially the atheists, man has absolute freedom to become what he wants and his responsibility too is absolute.

\section{d. Situatedness}

The existentialists conceive of freedom as situated. This absolute freedom of man is always exercised in particular contexts. His freedom is determined or limited by his body and its characteristics, his circumstances in a historical world, as well as his past. This situatedness makes freedom meaningful. A celebration of freedom that tends to ignore the context becomes either naive or illusory. In other words, man is absolutely free but not free to live in a fool's paradise.

\section{e. Existence}

The existence in question is human existence. In this connection, Nietzsche and Sartre conceive the human being as all and only what that being does. For Gabriel Marcel, existence is participation in the life of others or the community where man perceives himself as a being among beings.

\section{f. Irrationality/A bs ur dity}

Absurdity is a common theme among the existentialists. It has various nuances, but for many of the existentialists it suggests that nature is without any design or reason for existing. Although the physical science makes attempts at explaining the universe, it ends up mystifying it all the more, in the view of Albert Camus. Thus, the achievements of the natural sciences also empty nature of value and meaning since the scientifically described cosmos cannot answer our questions concerning value or meaning (Lescoe, 1974, p. 355; Burnham, 2018, para. 13). Absurdity is therefore a part of life. Another important sense of the absurdity is that, in Sartrean conception, in becoming myself I must be what I am not. Any attempt to escape this absurdity leads to bad faith.

\section{g. The Crowd}

While most of the existentialists conceive of a healthy means of associating with others as coesse (Marcel), I-thou (Buber), Being-with (Heidegger), solidarity (later Camus), etc, they all abhor the idea of an individual being lost in a group as a de-individuated or faceless individual. This is a manifestation of inauthenticity. Such individual accepts values from others uncritically instead of forming them authentically in freedom and anxiety. Such is the band wagon mentality.

www.jiels.com
These themes are of great importance to the existential discourse and will feature prominently in the discussion of the Afro-existential approach.

\section{THE AFRO-EXIS TENTIAL VIEW OF THE HUMAN PERSON}

The African worldview is basically existential. By this is meant that the African focuses on existence rather than speculating about life and the world. Hence, we argue that for the African too, existence precedes essence. This is seen in the personal Igbo names Ndubuisi (life is primary) and $N d u$ ka $a k u$ (life supersedes wealth), and in the proverbs: Nwa mkpi si ka ahapu ofo uto gooro ya ofo ndu n'ihi na onye dindu ga-etoriri uto (The he-goat requests that people wish him life first instead of growth because one who is alive must grow), and Ma onwu egbughi ji eji chu aja, o gaepuriri ome (If the sacrificial yam remains alive, it must germinate/make something out of its life). The African does not really speculate about life or the world, substance, categories, matter or form. Whatever discourse he engages in must have a bearing to his quality of existence. Hence even when he talks about the unseen realities such as God and the other beings in the African pantheon, as well as ancestors and other unseen realities, he talks of them as they impact on the quality of the human life. This human life or existence for the African is necessarily communalistic.

The idea of African communalism resonates in the academic circle. The idea suggests that Africans emphasize community living. It is also often understood to suggest, wrongly though, that the individual is swallowed up in the community and has no distinct life (Onah et al, 2016, p. 225) whereas existentialism lays emphasis on the individual. What then is the place of the individual in the traditional African society? Does he really have a distinct life? Is he free? Has he a voice? Or are his voice and concerns suppressed in the society? Are his rights and privileges preserved or are they sacrificed at the altar of communalistic concerns? The afro-existentialist view suggests that communalism added to the quality of life of the individual in the traditional society. We shall examine this existential outlook briefly here.

The traditional Igbo people, like other African tribes, lived in communities which formed the bedrock of existence in Africa. These communities were made up of basically descendants of common ancestors. These existed not just as a conglomeration of people sharing a particular geographical space, but also as a union of people sharing their lives together (Onah et al, 2016, p. 226). For Edeh (1985) the traditional Igbo community is "a societal set-up in which there is an intimate face-to-face interaction. Relationship is on a personal, human basis as distinguished 
from the predominantly impersonal relationship that exists in today's urban society where everyone minds his or her own business" (p. 56). Hence, the sharing of the basic conditions of a common life constitutes the bedrock of the Igbo community. Such a community is made up of families and kindred that come together to form a village. They are thus united by a common language, culture, and thought pattern. In such a community each member had his rights respected. On his part, the individual knew that he had responsibilities to the community. He earned his position in the community through hard work.

In the traditional Igbo community, there was a show of mutual concern by almost every member of the community. This could be as a result of the "we" feeling that pervaded the traditional society or simply the knowledge that what happens to one member of the community would eventually affect me. For instance, an Igbo adage says, onye huru okuko ebe o ji ukwu abo nsi ya chuo ya maka na o maghi onye ga-ata ukwu ya (One who sees a fowl scattering faeces with its legs should chase it away because it is not certain who will eventually eat the legs). In this connection, Ezedike (1995) paraphrases K. C. Anyanwu thus: "there is nothing like a solitary individual in the African (Igbo) cultural scheme of reality owing to the belief that all forces are perpetually in interaction with one another and interpenetrating each other" (p. 246). This is not far from Mbiti's (1969) understanding of the African communal life as "I am because we are and since we are, therefore I am" (p. 108). This suggests that the traditional community, though acting as a unit, was made up of individuals. It was individuals that made the community possible. Yet they were not isolated individuals because communalism is "essentially the spiritual communion of a society; the spirit of being one community, of being one with one's community, of belonging fundamentally to one another and to the community; the consciousness that instinctively orients my search for meaning in life to the appreciation or valuation of the community" (Odimegwu, 2007, p. 7). Essentially, as Agbakwuo (2013) opines, "for the Africans, to be is to-be-with and the purpose of existing, that beingwith, is to ensure a continuous enhancement of life and its optimal transmission" (p. 16).

This social set up derives its meaning from a sense of communion which is the animating principle. From the above it is discernible that the community is constituted by various individuals who share a common life and heritage. Nevertheless, the community is prioritized in the sense that the needs of the community supersedes and is ranked above the needs of the individuals, even though the individuals are the actors in the community (Onah et al, 2016, p. 226). What this implies is that the individual works strenuously to www.ijels.com realize his personal goals and optimize his abilities, but he never goes outside the boundaries set by community concerns. He "orders all his efforts and aspirations in the light of the whole" (Ezedike, 1995, p. 246).

In the traditional Igbo society, an individual was valued according his personal achievements, his relationships and his contribution to the society. It was a well known fact that otu osisi anaghi agho ohia (a tree does not make a forest) and that otu aka anaghi eke ngwuwu (one hand cannot tie a parcel). Everyone also understood that onye lie onwe ya, otu aka ya aputa n'elu ili (if a person buries himself, one of his hands will appear above the grave). In other words, however wealthy one was in material goods, one needed to be in communion with other members of the community because igwe bu ike (there is strength in communion). Development, in the traditional igbo society, was driven by this conviction that the way forward was to move with the community.

\section{AN AFRO-EXISTENTIAL APPROACH TO THE DEVELOPMENT OF THE NIGERIAN SOCIETY}

Colonization, in our view, is the worst thing that happened to Africa, in general, and Nigeria, in particular. It was a fight against the African and his existential consciousness. Founded as it was on racism, colonization employed every possible means to prove the superiority of the white over the black race. To achieve this, the colonizers had to put in action what Achebe (1989) describes as the desire "in Western psychology to set Africa up as a foil to Europe, as a place of negations at once remote and vaguely familiar, in comparison with which Europe's own state of spiritual grace will manifest" (p. 3). Today, colonialism subsists in neo-colonialis $m$.

To continue in this trend of blaming colonization and the West is, however, to abandon the existentialist thrust of this paper. Granted that the colonial masters created what I dare to call strange bedfellows through the 1914 amalgamation, the existentialist would ask, what do I make of this entity that has been created? We are now one Nigeria, so what next? What is the way forward in this geographical space into which I have been conscripted? This is where the Afroexistential approach to development comes in. The Afroexistentialist approach is resonant with themes common to both existentialism and the African worldview. These themes would be discernible in the following passages.

The first issue we shall address is the role of the Afroexistential discourse which could be developed as an approach in African philosophy. According to Marx (1947), "philosophers have hitherto only interpreted the world in various ways; the point is to change" (p. 199). The Afro- 
existential approach believes that philosophy should be a way of life. Philosophy should add to the value of life by discussing things relevant to the improvement of the quality life. Over and above this, philosophy should be practical. Russell (1961) in the preface to his History of Western Philosophy contends that philos ophy has always been a part and parcel of the life of any community. Philosophy is not just an empty chatter of an otherwise idle group of people, or endless argument about anything and everything. It is an enterprise that has a bearing on the life of the society. To this extent, "philosophers are both effects and causes: effects of their social circumstances and of the politics and institutions of their time; causes (if they are fortunate) of beliefs which mould the politics and institutions of later ages" (Russel, 1961, p. 7). Philosophers have the task of shaping the future of the society whose philosophy has shaped their thoughts. If Europe was able to develop itself and reach out to dominate other parts of the world, it is because philosophers through the ages shaped their perception of reality. If other philosophers whose thoughts were considered empty speculations by the existentialists were able to achieve this, then the existential discourse should be properly channelled in Nigeria to achieve a home grown development.

A major problem of the Nigerian today is that he lives a borrowed, and therefore, inauthentic life. Colonial education was one of the major tools used to disorient Nigerians. Genuine development begins in the mind as ideas. Hence, the aphorism, "ideas rule the world." There is therefore a need to develop the mind of the average Nigerian. There is a need to use education in contemporary times to decolonize the minds of Nigerians. This could be done through a well-articulated educational curriculum based on indigenous philos ophy of education relevant to our cultural milieu, or that which is consistent with our traditional values or cultural matrix. The average Nigerian is neither here nor there. Granted that the western brand of education offers opportunities to job seekers, it was designed both in structure and curriculum to disorient the African mind or existential consciousness. The result is seen in such experiences as narrated by Achebe (1989): "Three or four weeks ago my wife, who teaches English in a boys' school, asked a pupil why he wrote about winter when he meant the harmattan. He said the other boys would call him a bushman if he does such a thing!" (p. 44). That is to say that colonial/western education teaches the African to be ashamed of his identity; his past, and his environment which he is helpless to change in any remarkable way. The Afro-existential approach should aim at teaching the individual to live authentically. Only then can we think and work together to achieve an authentically African development.

The western existentialists' understanding of freedom is also not far removed from the African notion of freedom. I am free to make of myself what I will, and I take responsibility for what I make of myself. The African notion of freedom is limited by this responsibility which is to the community. The African is absolutely free within the community. The absoluteness is limited by community concerns. According to Onwu (2002), "individual existence and freedom are appreciated, but they are delicately balanced with the underlying philosophy of life-incommunity" (section 4.5, para. 1). This type of freedom could then be described as freedom within rather than freedom from the community. It is conscious of the fact that one person's freedom ends where the other person's freedom begins. This is because, basically, "Africans do not see themselves as individuals living independently, but rather as people living in a community interdependently, with communal responsibilities" (Agbakwuo, 2013, p. 162). The notion of absolute freedom which the Nigerian politicians seem to operate with is part of our undoing. They seem to forget that they are responsible, not only to themselves but also to the larger society. This seems to be another effect of the amalgamation where people now struggle to have a share of the national cake without care for how the cake is to be sustained so that it could reach everybody. The Afro-existential approach to development would involve a re-orientation bordering on African communalistic notion of freedom.

The Afro-existential approach embraces a contextual approach to development. Nku di na mba na-eghere mba nri (the firewood in a particular clime serves for their cooking) is a popular Igbo aphorism. While we think globally, there is a need to act contextually. This contextual approach stresses the need to focus our developmental effort on our peculiar situation in Nigeria. This would be helped by the development of independent thought. No person can be considered mature; that is, fully developed, without the capacity of independent thought. As long as one still accepts uncritically whatever one's parents or significant others tells one, one cannot be said to be mature. It is only when one can reflect independently on those things and accept or reject them on the strength of critical reflection that one can be said to be mature. It is against this background that we argue alongside Serequeberhan (1994) that "we contemporary (Nigerians) need to confront the question of our 'maturity' at its most fundamental level - on the plane of philosophic reflection" (p. 14). Philosophic reflection, we argue, is a pointer to mental independence. This mental independence, which the afro-existential 
approach promotes, is a prelude to contextual development. Independent thought would help us identify and prioritize our real needs, and develop accordingly.

Since philosophy engenders a critical attitude, the Afroexistential approach must engender a reflective action. It is a call to question the unquestionable; to challenge the status quo. It raises such questions as: Why are we backward? Why has the abundance of natural resources not resulted in a developed economy? Why have countries less blessed by nature faired far better than we have in Nigeria? The first obvious truth we discover here is that no one can develop who has no capacity for self-thought. Hence we discover that "the pure and simple reason for [Nigeria's] backwardness in recent times, despite the fact of political independence, remains that the [Nigerian] has refused to think for himself..." (Emedolu, 2010, p. 13). If the political elite do appreciate the need for critical self-thought, why would they willingly collaborate with external forces to keep their dear country perpetually underdeveloped? And if the masses really think for themselves, why would they worship the same people who oppress them? Hence, the major solution to the problem of underdevelopment in Nigeria is what Emedolu (2010) describes as "a systematic education in mental independence" (p. 13). This is what we refer to as the development of a critical attitude. This has been the age-old secret of national development.

Critical self-thought is both a sign of, and a stimulus for, development. Self-thought does not imply a rejection of any idea because it is not original to you. It is first of all considering Davidson's (1992) thought-provoking questions: "But why then adopt models from those very countries or systems that have oppressed and despised you? Why not modernize from the models of your own history; or invent new models?" (p. 19). These questions are very significant because the answer or answers provided show the level of maturity in self-thought. There may be reasons to consciously and voluntarily borrow models that have been tested and trusted. After all, some countries have achieved a developed economy by technology transfer. There is however no reason to swallow hook, line and sinker such models as have been practically forced down your throat. Even in the case of voluntary borrowing, such models have to be applied critically because certain conditions may facilitate or hinder their proper functioning. While inventing one's own model or modernizing models from history cannot be faulted, borrowing already successful models critically may make for faster progress. This is apparently what Nwodo (2004) refers to as a higher synthesis; a situation where the best of two cultures or models could be extracted and highlighted. You have been doing something in a rather crude and slow way and you get www.ijels.com an idea of modernizing it and lessening the hassles involved; that is progress. Both Hegel and Marx recognize development in apparent opposition such that a new idea or reality challenges the existing idea or reality; the two are then resolved in a new and higher idea or reality. The process goes through thesis and antithesis to produce a synthesis. This is opposed to the idea of insisting on generating an indigenous model. An indigenous model is not out of place when that is possible but it does not rule out the idea of a customised borrowing. However, it must be noted that our condition in Nigeria is not helped by unhealthy rivalry among the various ethnic nationalities, interest groups, and professional bodies, to mention a few. Indigenous creativity is suppressed by every means, not excluding death. This has contributed in no small measure to the phenomenon of brain drain whereby those who are capable of critical self-thought and of generating novel ideas are lured away to where they are appreciated more. The implication is that we keep losing our intellectual as sets to the developed nations where independent thought is appreciated.

Another area this lack of contextualization manifests itself is the area of industrialization. We see that the much touted "oil fall" has not resulted in a developed economy or infrastructure. Not many industries have developed in Nigeria either. Even the agricultural sector which was part of the mainstay of the colonial economy in Nigeria and the post-independence Nigeria of the 1960s and 70s has been left comatose. The situation is such that Nigerian has relied heavily on importation; even of such things that Nigeria ordinarily produces. What is really not imported in Nigeria; from consumable farm products like rice, chicken and animal hides to automobiles? But Nigeria has several rice producing communities that could be boosted by mechanization and improved species. Achebe (1973) wrote that while he was growing up, probably in the 1940s, "to say that a product was Ibo-made was to brand it with the utmost inferiority" (p. 9). That is why, as Isichei (1976) corroborates, textiles made in Nsukka, for instance, would be branded "made in England" to have a market value ( $p$. 31). This trend has continued to this day. Few people believe in the authenticity of made-in-Nigeria goods. Some others who abhor them do so not on the basis of the authenticity, or otherwise, of the products but on the basis of class. They suppose it is below their dignity to use locally manufactured products. Some who patronize them are only constrained to do so. How can we develop with this mindset? We need to accept our existential realities, our facticity.

Successive Nigerian governments have continuously sacrificed indigenous and contextual developmental 
interests by a commitment to always seek foreign developmental aid instead of setting in motion an aggressive process of industrialization. This is so much so that there is hardly any major industry in Nigeria that is indigenous. Shell BP, for instance, and other foreign oil firms have continued the monopoly in oil explorations in Nigeria. To this end Nyerere (1968) asks, "Could we agree to leave the economy of our country in the hands of foreigners who would take the profits back to their countries?" (p. 25). But these are part of the terms of the aids. We need to develop critical self-thought. We need to reflect on our actions and inactions. Nigeria boasts of four oil refineries that have been moribund almost since their establishment, with the result that petroleum products are also part of the products Nigeria imports. How can a nation that does not produce its needs advance? In this way Nigeria has continued to enrich the developed economies by default while holding tenaciously to her learned helplessness. While we can blame the situation on a number of forces beyond what is evident to the common mind, the challenge of the Afro-existential approach is to take the responsibility and rise to the challenge.

It bears repeating that the Afro-existential approach demands a mental revolution in Nigeria and the Nigerians. There is an urgent need to revolutionize the Nigerian mentality. In the words of Chinweizu (1978), "we need something like a communal mental bath, one in which we shall scrub the crud off one another's backs..." (p. xx). It is something akin to a counter-brainwashing. In Achebe's (1989) thinking, "here then is an adequate revolution ... to help my society regain belief in itself and put away the complexes of the years of denigration and self-abasement. And it is essentially a question of education, in the best sense of that word" (p. 44). It demands an education that takes into consideration our situatedness. Nkrumah (1963) seems to be making this same point when he noted that "our philosophy must find its weapon in the environment and living conditions of the African people" (rpt. in Mutiso \& Rohio, 1975, p. 644). The situation in question is that we have become disoriented. The traditional African was neither a loafer, a beggar, nor a swindler. He loved to produce his life. He was judged by what he produced. This was the basis of rewards in the community. To be recognized and given serious responsibilities in the community, one had to distinguish oneself by what one produces. Today, the situation has changed. Hard work is despised. People look for easy money and are given titles and accolades for just being rich, irrespective of the means. And then we have beggars under various pretexts littering the streets. The task of the existential discourse here is to initiate what Nietzsche would call the revaluation of values.
Closely related to the foregoing is the idea of crowd mentality. The Afro-existential approach celebrates the quest of the traditional African to distinguish himself as an individual; to stand up in order to be counted. The individual was inseparable from the community, as it were. Nevertheless, he was not anonymous in a faceless crowd. The community was also not a crowd. In Nigeria today, everybody seems to be enveloped by the crowd mentality, the band wagon effect. The dictum is, "If you cannot beat them you join them." And so we get lost in the crowd. People do things or refrain from doing things because others are doing or are not doing same, as the case may be. The Afro-existentialist approach abhors the crowd mentality or the de-individuated personality who has no capacity for critical self-thought.

The Afro-existential discourse is also conscious of history. In that regard, the re-orientation it advocates has to deal with the history of African civilization. The colonial situation infected the African psyche with learned helplessness. According to Diop (1986), "the philosophy of the colonizer was to make it very clear that the colonized people could do nothing for themselves without the assistance of the colonizing people" (p. 349). The colonial education convinced the African that he was heading for extermination by hunger, ignorance, lack of technology, and what have you, until the white man appeared as the longawaited messiah. Hence, it was the "white man's burden" to bring Africa up to speed with the rest of the world. To drop this learned helplessness, therefore, we need to go back to history to see that Africa was developing at its own pace before the colonial contact. Palmberg (1983), for instance, cites the documented amazement of some Dutch visitors on the level of organization and development they saw in the city of Benin (p. 83). That was in the 15th century. According to Sartre (1963), "we only become what we are by the radical and deep-seated refusal of that which others have made of us" (p. 15). This is a refusal of my present situation as final. The re-orientation would therefore be an honest attempt to show the Nigerian that, imperfect as his pre-colonial past may have been, it was not inglorious, and he did not lack dignity. It is the conviction of Nwodo (2004) that "once the [Nigerian] has recovered, has regained his dignity, self-respect and self-confidence, he is ready to invent a future for himself" (p. 234). This is because he believes, in line with Achebe, that "the African destiny/destination as a process starts with a recreation of the past" (p. 234). This is in line with the argument of Spady (1986) that "to avoid a deformed African personality one must be conversant with the full range of one's ancestral past, not just to establish self-pride but to use it as the basis for constructing a modern civilization..." (p. 96).

Page | 712 
Since this return to the African past is not just meant for one to glory in a lost past, the next step in this philosophical reorientation of the African consciousness is to ask: "where did we get it wrong?" Our conviction is that the traditional Africans got it wrong because they seemed to have lacked the critical attitude that propels technological advancement. The traditional African society apparently was an uncritical society. They made inventions probably out of necessity but such inventions were hardly improved upon so long as they tended to satisfy the original need they were meant to serve. For instance, Rodney (1972) maintains that Europe borrowed much of her nautical instrumentation from the North Africans (p. 98); but Europe went ahead to develop the technology and build ships while Africans remained at the level of canoes. Also Achebe (1989) cites the testimony of the British art historian, Frank Willet who describes the revolution an African art work had caused in Europe, influencing great European artists like Picasso and Matisse (p. 16). Yet such works go unnoticed in Africa. Europe may also have developed in this manner until the renaissance which eventually led to the enlightenment. Consequent upon the age of reason, every as sumption was challenged in almost every field of learning. But Africa was not as fortunate. The Afro-existential discourse, therefore, has to champion this course.

Since the excursion into the African past has furnished us with a civilization and with the bane of that civilization, the re-orientation now has a focus. The history we have explored should guide us in this re-orientation. Accordingly, Wilson (1993) asserts that "it is through studying the history of our people that we come to understand ourselves as individuals and as a people." And then "we have to use history as a means of reconstituting our personality and restructuring ourselves" (p. 54).

\section{CONCLUSION}

The existentialist discourse or the Afro-existential approach, as the case may be, is, in a nutshell, a realistic philosophy. It gets itself engrossed with the existential realities of the individual, what confronts me in my present situation. It also concerns itself with the choices I make in my given situation and the implication(s) of such choices. The basic situation that we are confronted with in this discourse is the underdeveloped state of Nigeria. Who do we blame? Although the existentialists do not overly ignore history, they are concerned with my present situation and the choices that confront me. Hence, we must conclude by asserting that what has happened to you is not as important as what you make of it. We must make the right choices and take the right steps today as philosophers to establish our relevance through the existential discourse.

www.ijels.com

\section{REFERENCES}

[1] Achebe, C. (1973). "The Role of the Writer in a New Nation." In G. D. Killam (Ed.). African Writers on African Writing. London: Heinemann.

[2] Achebe, C. (1989). Hopes and Impediments. Selected Essays. New York: Anchor.

[3] Agbakwuo, J. O. (2013). The African: His Religion and Cosmology. Umuahia: Lumen.

[4] Burnham, D. (2018). "Existentialism." The Internet Encyclopedia of Philosophy, ISSN 2161-0002. Retrieved from http://www.iep.utm.edu

[5] Chinweizu (1978). The West and the Rest of Us. Lagos: NOK.

[6] Copleston, F. (1956). A History of Philosophy, vol. 11: Logical Positivism and Existentialism. London: Continuum.

[7] Davidson, B. (1992). The Black Man's Burden. Ibadan: Spectrum.

[8] Diop, C. (1986). In Ivan Van Sertima (Ed.). Great African Thinkers: Cheikh Anta Diop, vol. 1. New Jersey: Trans actions.

[9] Edeh, E. M. P. (1985). Towards an Igbo Metaphysics. Chicago: Loyola University.

[10] Emedolu, C. C. (2010). Originality: Some Reflections on Authentic Development in Africa, vol. 2. Port Harcourt: University of Port Harcourt.

[11] Ezedike, E. U. (1995) "The Individual in an African Communal Universe." In Andrew F. Uduigwomen (Ed.). From Footmarks to Landmarks on African Philosophy (2nd ed.). Lagos: O. O. P.

[12] Isichei, E. (1976). A History of the Igbo People. London: Macmillan.

[13] Lescoe, F. (1974). Existentialism: with or without God. New York: Alba House.

[14] Marcel, Gabriel. "Existence." New Scholasticism 38 (1964). Web. 18 Apr. 2018.

[15] Marx, K. \& Engels, F. (1947). "Thesis on Feuerbach." An Appendix to The German Ideology, Parts I and II. Edited with Introduction by R. Pascal. New York: International Publishers

[16] Mbiti, J. S. (1969). African Religions and Philosophy. New York: Anchor.

[17] Nkrumah, K. (1963). Neo-Colonialism. London: Panaf. Rpt. In G. M. Mutiso \& S. W. Rohio (Eds.). (1975). Readings in African Political Thought. Oxford: Heinemann.

[18] Nwodo, C. S. (2004). Philosophical Perspectives on Chinua Achebe. Port Harcourt: University of Port Harcourt.

[19] Nyerere, J. K. (1968). Ujamaa - Essays on Socialism. New York: Oxford UP. 
[20] Odimegwu, I. F. H. (2007). "How Communalist is Africa?" In Philosophy and Praxis: Journal of the Nigerian Philosophical Association, 3, 1-9.

[21] Onah, O., Ezebuilo, H. \& Ojiakor, T. (2016). “The Place of the Individual in the Traditional African Society: A Philosophical Appraisal." International Journal of Social Sciences and Humanities Review 6(3), 225-229.

[22] Onwu, E. N. (2002). "Ụzọ Ndụ na Eziokwu: Towards an Understanding of Igbo Traditional Religious Life and Philosophy." Ahajioku Lecture series, 2002. Retrieved from http://www.igbonet.com.

[23] Palmberg, M. (Ed). (1983). The Struggle for Africa. Andree E. M. K., Mai Palmberg \& Howard Simson (Trans.). London: Zed.

[24] Rodney, W. (1972). How Europe Underdeveloped Africa (2009 edition). With introduction by Vincent Harding. Abuja: Panaf.

[25] Russell, B. (1961). History of Western Philosophy, And its Connection with Political and Social Circumstances from the Earliest To the Present Day (New Ed.). London: Allen.

[26] Sartre, J. P. (1973). Existentialism and Humanism. London: Methuen.

[27] Sartre, J. P. (1963). Preface. The Wretched of the Earth by Frantz Fanon. Trans. Constance Farrington Middlesex: Penguin.

[28] Seers, D. (1967). The Meaning of Development. IDS Communication 44. Brighton, UK: Institute of Development Studies. Retrieved from https://www.cgdev.org/blog/what-development

[29] Serequeberhan, T. (1994). The Hermeneutics of African Philosophy: Horizon and Discourse. New York: Routledge.

[30] Shah, S. (nd). Development: Meaning and Concept of Development. Retrieved from http://www.sociologydiscussion.com/society/develop ment-meaning-and-concept-of-development/688

[31] Simpson, M. C, (2016). "A Fascinating History of Existentialism." Tribune News Service, Times Colonist, March 12, 2016.

[32] Spady, J. G. (1986). In I. Van Sertima (Ed.). (1986). Great African Thinkers: Cheikh Anta Diop, vol. 1. New Jersey: Transactions.

[33] UNDP (2015). 2015 Human Development Report Statistical Annex. Pdf.

[34] Wilson, A. N. (1993). The Falsification of African Consciousness: Eurocentric History, Psychiatry and the Politics of White Supremacy. New York: African World Infosystems. 